\title{
Sumerian Arsenic Copper and Tin Bronze Metallurgy (5300-1500 BC): The Archaeological and Cuneiform Textual Evidence
}

\author{
Lucas Braddock Chen \\ Foundation for the Advancement of Anthropology \& History, Menlo Park, USA \\ Email: Braddock9955@gmail.com
}

How to cite this paper: Chen, L. B. (2021). Sumerian Arsenic Copper and Tin Bronze Metallurgy (5300-1500 BC): The Archaeological and Cuneiform Textual Evidence. Archaeological Discovery, 9, 185-197. https://doi.org/10.4236/ad.2021.93010

Received: June 19, 2021

Accepted: July 9, 2021

Published: July 12, 2021

Copyright $\odot 2021$ by author(s) and Scientific Research Publishing Inc. This work is licensed under the Creative Commons Attribution International License (CC BY 4.0).

http://creativecommons.org/licenses/by/4.0/

\section{(c) (i) Open Access}

\begin{abstract}
Copper was one of the first metals to be utilized since 8000 BC. Arsenic copper became popular due to its lower melting point and decreased metal porosity, allowing for the creation of longer metal blades. Tin bronze began appearing around $3500 \mathrm{BC}$, and its superior recyclability and malleability made it the favorite metal alloy until the prevalence of iron. Bronze alloy was limited by its requirement of tin, which was more difficult to acquire than copper in ancient Mesopotamia. This manuscript describes the ancient trade of copper and tin based on the cuneiform texts. The paper will also list the cuneiform texts that described steps of metallurgy, including the tools, furnaces, and crucibles utilized in Sumerian metallurgy. This paper reports the analysis of the metallurgy techniques described by cuneiform to the chemical analysis of copper artifacts in order to provide a better understanding of the meaning of Sumerian metallurgy cuneiform texts.
\end{abstract}

\section{Keywords}

Copper, Bronze, Cuneiform, Metallurgy, Mesopotamia

\section{Introduction}

Copper was one of the first metals to be utilized worldwide due to ubiquitous ore deposits, its low smelting temperature, and its coveted lustered appearance (Patterson, 1971; Moorey, 1988; Oudbashi et al., 2020; Radivojević, 2010; Garfinel et al., 2010). There has been long-standing debate as to whether metallurgy technology arose spontaneously across the globe, or whether it represents a process of knowledge diffusion (Wertime et al., 1973; Killick, 2009; Thornton, 2009). Whichever model is more reflective of metal history, it is important to remem- 
ber that the metallurgy technology in each region developed its own local characteristics and methodologies; each area of the world has its unique geography, natural resources, and history of innovation. For example, what kind of copper ore is available: pure copper, copper oxide, or copper sulfide? What kind of fuel is available: wood, dried grass, or charcoal? What can be used to enhance fire temperature: forced air flow through reed straws, hand fans, or bellows? What material is available to create casting molds: open sand, clay, or lost wax (Helwing, 2017; Wischnewski, 2017)?

This paper will explore the development of arsenic copper and tin bronze metallurgy technology from 6th millennium BC Sumer, when arsenic copper was utilized, until around $1500 \mathrm{BC}$ when the rise of iron metallurgy required different sets of technology and tools to purify and cast metal with a much higher melting temperature. It will illustrate some of the cuneiform textual evidence, including texts that describe the steps of copper metallurgy.

\section{Background: Sumer's Copper History}

Copper metallurgy has been associated with some of the earliest complex civilizations of the world (Golden, 2014). Cold annealing of native copper was found as early as the 8th millennium BC in Southwest Asia (Roberts, 2009; Matthews \& Fazeli, 2004; Raymond, 1986). Early copper metalwork was found in 5th millennium BC Varna, Bulgaria, which showed evidence of metal casting (Svend, 2017). Copper smelting specialization has also been documented on the Levantine coast in the 6th millennium BC (Borschel-Dan, 2000; Garfinkel et al., 2014).

Ancient Sumer and southwestern Iran were unique in that they showed the first evidence of arsenic copper utilization, found, for example, from $5300 \mathrm{BC}$ in Susa (Ryck et al., 2005). While pure copper annealing was documented in Northern Mesopotamia before 6000 BC (Levey, 1959), arsenic copper first became prevalent in Southern Mesopotamia in the second half of the 6th millennium BC (Svend, 2017).

There is debate as to whether arsenic copper was the result of deliberate addition of arsenic to copper during the smelting process or whether arsenic was a carry-over compound during the smelting process (Wischnewski, 2017; Ryck et al., 2005). While natural copper ores, especially those from Anatolia, may possess some naturally occurring arsenic, it is generally believed that arsenic content over 5\% is evidence of deliberate addition (Ryck et al., 2005). During copper smelting, arsenic sulfide can be added via either orpiment or realgar, two pigments well known from ancient Egypt (Daniels \& Leach, 2013; Levey, 1959; Stech, 1999). Copper comprised of greater than $2 \%$ arsenic possesses useful chemical properties (Raymond, 1986; Moorey, 1999). Instead of the reddish copper appearance, arsenic copper exhibits a silvery luster and was valued as a luxury item (Svend, 2017). Arsenic copper alloy demonstrates greater elasticity and structural durability, and thus, could be fashioned into ornaments more easily (Allen et al., 1951). 
Arsenic copper also increased the range of weapons Sumerians were able to construct. Arsenic added to copper reduces metal porosity, thus creating a stronger alloy (Junk, 1973). While battle axes and maces could withstand metal porosity, daggers could not. The absence of porosity prevents pitting of the metal, thus allowing casting of a longer metal blade. It was observed that, with the invention of arsenic copper, average Sumerian daggers increased from an average length of $34 \mathrm{~cm}$ to $60 \mathrm{~cm}$ (Svend, 2017).

Additionally, with a lower melting temperature and decreased porosity, arsenic copper could be cast more easily (Junk, 1973). Instead of being limited to open sand molds where castings had to be more carefully monitored, metalsmiths could pour melted arsenic copper into lost-wax molds without having to worry about uneven filling or undetected bubbles (Zettler \& Lee, 1999). With lost-wax casting using pre-formed clay or pottery molds, a coppersmith could create more complex objects such as crowns, scepters, or the spokes of wheels, thus fostering innovations in metallurgy (Svend, 2017).

Arsenic copper represented the height of copper metallurgy until the arrival of bronze, an alloy of copper and tin. Sumer was also the birthplace of bronze technology, most likely owing to the area's long history of copper working knowledge and its flourishing copper smelting centers (Lopez, 2009). Tin bronze was introduced around the middle of the 3rd millennium BC, whereas the first true evidence of bronze is known from around $3000 \mathrm{BC}$ at Ur in Mesopotamia (Pollock, 1999).

Tin bronze provided several advantages: while copper has a melting temperature of $1084^{\circ} \mathrm{C}$, the addition of tin lowers the melting point to $950^{\circ} \mathrm{C}$ (Raymond, 1986). The lower melting temperature was easier to achieve and maintain, thus making the pouring and casting of metal even more manageable. The ease of casting increased the rate of production and thus accelerated the bronze industry.

Tin bronze also had the additional advantage over arsenic copper in its ability to be recycled and reused. Due to their precious nature, copper artifacts were continuously recycled and repurposed (Moorey, 1982). In "Laws of Eshnunna", a bilingual (Sumerian and Akkadian) composition which may have originally been composed in the late 3rd millennium BC but is known from Old Babylonian Akkadian (early 2nd millennium BC), one clause stipulated that workmen issued copper tools for the harvest must return metals of the same weight at the end of the season, even if in scraps (Roth, 1995). Metalware and scraps were melted down and recast, but arsenic is a volatile element and can evaporate during the smelting process (Crawford, 2004; Shibayama et al., 2010). Repeated hot annealing of arsenic copper would gradually see a decline of the arsenic content and thus lead to degradation of the alloy (Greenfield, 2017; Mödlinger et al., 2017). The evaporated arsenic gas was most likely also toxic to the coppersmith; recent bone analysis of ancient metal workers at Chalcolithic Levant showed elevated levels of arsenic (Oakberg et al., 2000). Tin bronze, however, was superior in that it did not suffer from metal degradation with metal recycling nor 
give off toxic fumes, and this may have contributed to its gain in popularity among coppersmiths.

Tin copper compounds had additional advantages over arsenic copper. Like arsenic, tin could also reduce the amount of bubble formation in the copper cast. However, tin bronze provides much more structural strength than is found in arsenic copper. While arsenic copper was strong enough to make tools and weapons, its limited tensile strength restricted the length of arsenic copper weapons to be no longer than daggers (Lopez, 2009). With the availability of bronze, metalsmiths were able to create longer weapons such as sabers, larger constructs such as statues, or sturdier tools such as hoes, via casting (Crawford, 2004).

Through trial-and-error over the years, Sumerian metalsmiths defaulted to creating copper alloys with approximately $10 \%$ tin (Raymond, 1986). This ratio most likely represents a balance between better properties of tin bronze vs the high cost of tin metal due to difficulty of procurement. The limited supply of tin was one of the major reasons why, despite the superior performance of tin bronze, it did not supplant arsenic copper until 1500 BC (Greenfield, 2017). Here it is important to examine the supply of copper and tin during the Bronze Age, as Mesopotamia lacked natural metal ores.

\section{Results}

\section{1) Sumerian Copper Trade}

Mesopotamia in the 3rd millennium BC received copper through both land and sea routes. Traders were able to bring copper over land from the Zagros (present day Iran) and Taurus (present day Turkey) mountains (Muhly, 1973; Morr et al., 2013). Anatolian copper mines produced copper sulfides, which had to first be roasted into copper oxide before it could be smelted (Levey, 1959). It is thought that Anatolian copper was smelted in Tishmurna and Durhumit (near the mines of Boghazkeui and Kültepe) before being exported to Sumer (Collins, 2016). An extensive network of trading posts, based on the Old Assyrian trade route via Assur, was established such that the amount of copper imported increased over time (Leick, 2001). By the 2nd millennium BC, the annual import of copper from Anatolia to northern Mesopotamia via donkey caravan was estimated to be 10 tons (Mieroop, 2016).

In addition to the overland copper routes, Sumer also had a robust copper sea trade to three regions (Begemann et al., 2010): Dilmun, Magan, and Meluhha. Dilmun (present day Bahrain) was a major trading post connecting Mesopotamia, Oman, Iran and the Indus Valley (Giardino, 2019). Magan is present day Oman, a major source of copper ores. Meluhha refers to the present-day Indus Valley (Muhly, 1973), where the Harappan Civilization flourished from 2500-1700 BC.

There are records of many copper purchases from Tilmun by Ur during the Larsa period 2025-1763 BC (Muhly, 1973). It is estimated that several hundred kilograms of copper arrived annually from Tilmun to Southern Mesopotamia during the 3rd millennium BC (Giardino, 2019). Trades were carried out by "Tilmun boats" (má tilmun-naki). That Tilmun traders played a dominant role 
in the copper trade might be inferred by the fact that copper transactions were conducted using the weight standard of Tilmun, the "Tilmun standard" (na4 tilmunki) (Muhly, 1973).

One of the texts from Ur during the Lara period (2025-1753 BC) showed details of a copper trade with Tilmun:

2 ma-na kù-babbar;

5 İ-gǏš gur;

30 túg-hi-a;

Kaskal tilmunki-šè;

Nam urudu sa10-sa10-dè;

" 2 minas of silver

5 kur of sesame oil

30 garments

For an expedition to Tilmun

To buy copper there" (Muhly, 1973).

Tilmun was first mentioned in the Uruk IV period (4000-3100 BC), but its name appeared much more frequently in Early Dynastic period texts (2900-2350 BC) (Mieroop, 2016). By the end of the third dynasty of Ur, however, copper trade from Tilmun apparently declined. Instead, Magan appeared to have replaced Tilmun as the source of copper during the reign of Ibbì-Sîn (2029-2006 BC). The title of the office in charge of trade with Tilmun, the Alik Tilmun, no longer appeared in texts (Falkenstein, 1966). Instead, the title of ga-eš8 a-ab-ba, with connection to Magan, was used in association with trade:

"níg-šám-ma urudu má-ganki";

"merchandise for buying copper of Magan".

The texts from $2000 \mathrm{BC}$ referred to the quantity of wool and textile that were traded for copper (Leemans, 1960). With the shift in trade, Magan boats were increasingly described. They were characterized by their large size, with each able to carry 15 metric tons of material, and by their coating of water-proof black bitumen tar (Giardino, 2019).

As opposed to Tilmun, which was most likely a trading post, Magan was an actual site of copper production. Magan was referred to as KUR URUDU 4 月. $\square$ (mountain of copper) (Muhly, 1973). The importance of Magan copper can be determined by chemical analysis, since copper mined from Magan ores contained characteristic high nickel content. It has been determined that, among Sumerian copper artifacts from the 2nd to the 3rd millennium BC, about half possessed the characteristic high nickel content, averaging 0.05\% - 3.34\% (Giardino, 2019).

Copper trade with Meluhha, on the other hand, was not as well documented. It is thought that Mesopotamian cuneiform texts actually described two Meluhhas, one to the west (now generally believed to be located in present day Nubia and Ethiopia), while the other one was to the east and thought to be in present day west Pakistan in the Indus Valley (Dhavalikar, 1997). The Meluhha in the Indus Valley is believed to be the copper trading partner described in a Sargon I 
text by someone described as "Su-i-li-su, Meluhha interpreter" on a Mesopotamian seal (Kanika, 2021). Meluhha was located near two major copper deposits, the copper oxide ores in the Saindak, and malachite and azurite carbonate ores in the Raskoh Range (Muhly, 1973).

Trade with Meluhha was better documented during the second half of the 3rd millennium BC. The reliance of the sea trade route to the Indus Valley most likely accelerated during the Sargonic period when overland trade routes to the Zagros mountains were disrupted. The empire of Ur III, however, collapsed around 2000 BC. With the concomitant decline of Magan, the sea copper trade route was largely discontinued in favor of northern overland routes as new and cheaper sources of copper became available from Anatolia and Cyprus (Steinkeller, 2014).

As opposed to copper, the source of tin for Mesopotamia during the Bronze Age is not as well defined (Cuénod et al., 2015; Yener, 1993). First of all, tin and lead both have similar grayish-white appearances and were described interchangeably in Sumerian texts (Muhly, 1973). In Sumerian, the word an-na is actually used to describe both tin and lead (ePSD, 2021). The confusion persisted even to the Classical period, as tin was actually called plumbum candidum in Latin, or "white lead".

\section{2) Sumerian Metallurgy Technology}

Having reviewed the sources of Mesopotamian copper and tin bronze in Bronze Age Sumer, I turn to the cuneiform texts that provide evidence for the steps in the process of copper metallurgy. Copper in Sumerian was referred to as urud , while bronze was referred to as zabar

Copper ore exists in rock form and needs to be pulverized into pellets to allow for metal extraction during the smelting process. Copper ores were referred to as Urud hašum (urud ha-šum) (Levey et al., 1959). Mortars (naĝa) or pestles (gešgana) were already in existence during the Early Bronze age to grind grains into flour and it is believed that the same tools were used to process copper ores.

First, mortars and pestles were utilized to crush (gum and to grind (guru () ores into pellets of manageable size (Levey et al., 1959). Next, the crushed copper pellets were washed to remove soil impurities and were recollected via a sieve (sim, “to sieve” 陼). A text from 2200 BC shows that clay colanders with pores were covered with hair or wool to strain and isolate materials (Levey et al., 1959).

Processed ore pellets were next smelted in order to extract copper. Copper metallurgy arose after the development of pottery, and many believe that copper smelting initially occurred as an accidental pottery byproduct when copper in pottery glazing became congealed in the furnace and was extruded as small copper nuggets (Tylecote, 1992).

Furnaces used for copper smelting also evolved over time. Small furnaces were found dating as far back as 4000 BC in Assur, in northern Mesopotamia, a region which at the time exhibited cultural connections with the south (the 
so-called "Uruk culture") (Levey et al., 1959). The initial furnaces were constructed with clay and were of a circular design. The furnaces had openings at the bottom where fuel could be added, and had multiple side vents to allow for air drafts and thus, higher burning temperatures. Furnaces from the $3^{\text {rd }}$ millennium BC became taller (total height up to $100 \mathrm{~cm}$ ), and were now in the shape of a house. Fuel was kept inside the rectangular base of the furnace, and air vents in the shape of windows were added to the sides of the house-shaped furnaces in order to enhance air flow. Larger furnaces started appearing in Susa at the beginning of the $3^{\text {rd }}$ millennium (Levey et al., 1959). These were of a circular design and were topped with a dome. The furnaces were over $200 \mathrm{~cm}$ tall and are estimated to have reached temperatures up to $1100^{\circ} \mathrm{C}$. Deposits of calcium carbonate found inside a furnace in Khafaje in the Diyala region of central Mesopotamia are evidence that this type of furnace was used for smelting, rather than for pottery making. Calcium carbonate was an often-used flux agent, in the form of limestone, utilized in copper smelting to facilitate the isolation of copper, and its existence within the slag inside this furnace suggests its usage for copper metallurgy (Patterson, 1971).

There was another type of large furnace found dating to around $3000 \mathrm{BC}$, the "floor of eye" furnace, known from Levant and Northern Mesopotamia. This furnace was constructed on the floor of the shop, with a large central pit or "eye." While this type of furnace was easier to construct, its open-air design would not be able to achieve a high enough temperature for copper smelting. This type of furnace was most likely used for copper hot annealing, rather than for smelting.

In order to achieve the higher temperatures required for copper smelting, another design, the stacking furnace, also emerged (Levey, 1959). Multiple furnace elements were stacked vertically atop each other, achieving the height of a house. The utilization of these furnaces for copper smelting was confirmed by cuprite and malachite copper deposits found at the bottom of a furnace excavated in Khirbet el-Jariyeh.

The stacking furnace also utilized bellows at the bottom to fan flames and achieve high temperatures. The use of bellows was documented as early as the second millennium $\mathrm{BC}$, when a Larsa coppersmith received two goats "for the leather of the bellow" of the furnace (Faust, 1941). Another tablet reveals that reed pipes ${ }^{\mathrm{GI}} \mathrm{KA}$ IM direct flames into the furnace (Cros, 1910).

Within the furnaces, copper pellets were smelted inside crucibles, Sumerian abni $_{2}$ (ePSD, 2021). Crucibles were made of fired clay in order to endure the high furnace temperatures, and were found as early as 3000 BC at Amouq in Syria, near the northern extent of the Uruk culture and trade networks. During copper smelting, impurities were separated as floating slags and tapped off, with molten copper remaining in the crucible to be recovered (Hauptmann, 2014).

Copper metallurgy requires sustained and controlled flames, and the impor- 
tance of fire and temperature were recorded in some of the earliest cuneiform texts: "Fire is kindled, it should be a good fire, not a smoky or a fierce fire" (Levey, 1959); the text also mentions that the furnace fire needed to be kept going for four to ten days (Thompson, 1936).

Fuel was a critical component of fire, and cuneiform texts recorded different types of fuel used in the copper extracting process. Fires from 2000 BC in Palestine and Northern Mesopotamia mostly used dried shrubs and bushes (Levey et al., 1959). There is text showing the usage of styrax, mulberry or willow wood,

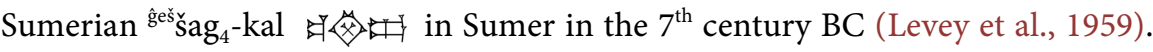
There are discussions as to whether charcoal ${ }^{\text {ges }} \mathrm{u}_{2}$-bil ${ }_{2}$-la ( ${ }^{\text {geš }} \mathrm{u}_{2}$-bil ${ }_{2}$-la) were used as fuel, as the archaeological evidence is ambiguous; it is difficult to differentiate between charcoal and accidentally charred firewood (Levey et al., 1959).

The combination of tin and copper to create bronze was a technological advancement known at an early time, as a $3^{\text {rd }}$ millennium BC hymn praised the god of fire, Gibil, for mixing copper and tin (Figulla \& Martin, 1953). A tablet from the $2^{\text {nd }}$ millennium BC showed a formula for bronze, namely " 10 minas of glittering copper and 2 minas of tin" and "900 shekels of copper and 70 of tin" (Wiseman, 1953). Similarly, a Sumerian text from the $3^{\text {rd }}$ millennium BC reads:

" $1 / 2$ talent, 5 minas and 1/3 shekel of copper plus 4 minas, 5 shekels of tin to make bronze (Strassmaier, 1889).”

For modern day calculations:

1 talent $=75 \mathrm{lbs}$ or 60 minas

$1 \mathrm{mina}=1.25 \mathrm{lbs}$ or 50 shekels

1 shekel $=0.4$ ounce

Smelted copper alloys were cast into molds for the final products. The earliest mold system was the open cast, in which a mold was created either in a sand tray or chiseled into the floor of the workshop (Lopez, 2009). The pattern on the shop floor for bronze casting was described as a "crevice" or ki-i-dar or nigissu

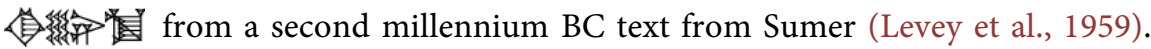
The lost wax method of casting was already developed by $2800 \mathrm{BC}$, in which a wax model of the final object was first created and wrapped with clay (Levey, 1959). Wax dissolved with heating, and the empty space left behind in the clay could be used to mold bronze. Molds used in bronze casting were called nighdea in Sumerian, written ${ }^{\text {urud }}{ }^{2} \hat{g}_{2}-\mathrm{de}_{2}$-a

The wax method was mentioned in a first millennium BC text: " 20 minas of wax were given to the smith to make a ni-bi-ri", which is associated with the Sumerian god Marduk $*$.

${ }^{\mathrm{d}}$ AMAR.UTU (Strassmaier, 1889). The lost wax method was also documented in the 3rd Dynasty of Ur, when a hubum ( ${ }^{u}$ hu-bu-um) forms part of a chariot, was made with one minas of copper (Limet, 1955). In

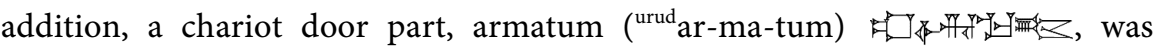
made with 2 minas and 16-1/2 shekels of copper. Additionally, it was noted that sheep fat, flour and oil were used as early as the end of the 3rd millennium BC to 
coat the molds for easier extraction (Wischnewski, 2017).

There were multiple classes of metal workers in $3^{\text {rd }}$ millennium Sumer. Simug 目, was a metalsmith who worked with all kinds of metals (Wischnewski, 2017).

Simug urudu worked primarily on copper 政 4 , specialized in bronze. There were also metal specialists, with tibira focused on hammering metals into shape, and kù-dím was a luxury smith who only worked with gold and silver.

\section{Discussion}

As compared to other ancient civilizations who underwent the Bronze Age transformation, the history of copper metallurgy is especially well documented in ancient Sumer due to the availability of cuneiform tablets. This paper outlines some of the known evidence of arsenic copper and tin bronze metallurgy, from copper and tin mineral acquisition, mostly achieved through trade, to ore processing, smelting, and casting. Unique aspects of Sumerian metallurgical tradition include their set of local fuels for smelting fires and their particular crucible and furnace designs.

The study of metallurgy history is hampered by the complicated history of copper artifacts, where each piece invariably underwent repeated cycles of salvage and re-tooling. Since each cycle of metal annealing adds new chemical signatures to the alloy, understanding the provenance of each ancient metal object via chemical or atomic analysis is complicated. The study of the history of metallurgy is thus substantially improved by a careful examination of the textual evidence, as this overview has shown. With up to $90 \%$ of the 500,000 cuneiform tablets available yet unanalyzed, there is a large treasure trove of potential metallurgy history yet to be discovered (Hardach, 2018). The interpretation of metallurgy cuneiform can be improved when cuneiform texts could be analyzed in the context of modern day chemistry in order to better understand the chemistry described by cuneiform. With digital cuneiform analysis becoming available, it is possible more information can be shed on the origin of metallurgy in ancient Sumer.

\section{Acknowledgements}

This work would not have been possible without my mentor, Dr. Kate Kelley. Thank you for your continued support and encouragement. I greatly appreciate your tireless guidance and advice, and am indebted to you for inspiring my interest in Mesopotamian history.

This research was supported by a fellowship grant from the Foundation for the Advancement of Archaeology and History.

\section{Conflicts of Interest}

The author declares no conflicts of interest regarding the publication of this paper. 


\section{References}

Allen, N. P., Schofield, T. H. et al. (1951). Mechanical Properties of $\alpha$-Solid Solutions of Copper, with Zinc, Gallium, Germanium and Arsenic. Nature, 168, 378-379.

https://doi.org/10.1038/168378a0

Begemann, F., Hauptmann, A. et al. (2010). Lead Isotope and Chemical Signature of Copper from Oman and Its Occurrence in Mesopotamia and Sites on the Arabian Gulf coast. Arabian Archaeology and Epigraphy, 21, 135-169. https://doi.org/10.1111/j.1600-0471.2010.00327.x

Borschel-Dan, A. (2000). 6,500-Year-Old Metalworkers: Humanity's 1st Smelting Furnaces Found in Israel? The Times of Israel, October 4.

Collins, P. (2016). Mountains and Lowlands: Ancient Iran and Mesopotamia. Oxford: University of Oxford.

Crawford, H. (2004). Sumer and the Sumerians. Cambridge: Cambridge University Press. https://doi.org/10.1017/CBO9780511816208

Cros, G. (1910). Nouvelles Fouilles de Tello. Paris: Leroux.

Cuénod, A., Bray, P. et al. (2015). The "Tin Problem" in the Prehistoric Near East: Further Insights from a Study of Chemical Datasets on Copper Alloys from Iran and Mesopotamia. Journal of the British Institute of Persian Studies, 53, 29-48. https://doi.org/10.1080/05786967.2015.11834749

Daniels, V., \& Leach, B. (2013). The Occurrence and Alteration of Realgar on Ancient Egyptian Papyri. Studies in Conservation, 49, 73-84.

https://doi.org/10.1179/sic.2004.49.2.73

Dhavalikar, M. K. (1997). Meluhha-The Land of Copper. South Asian Studies, 13, 275-279. https://doi.org/10.1080/02666030.1997.9628541

ePSD (2021). The Pennsylvania Sumerian Dictionary. http://psd.museum.upenn.edu/nepsd-frame.html

Falkenstein, A. (1966). Die Inschriften Gudea von Lagaš, 30. Rome: Einleitung.

Faust, D. E. (1941). Contracts from Larsa Dated in the Reign of Rim-Sin. New Haven, CT: Yale.

Figulla, H. H., \& Martin, W. J. (1953). Ur Excavations Texts: Letters and Documents of the Old-Babylonian Period (Volume 5). London: British Museum.

Garfinkel, Y. et al. (2014). The Beginning of Metallurgy in the Southern Levant: A Late 6th Millennium CalBC Copper Awl from Tel Tsaf, Israel. PLoS ONE, 9, e96882. https://doi.org/10.1371/journal.pone.0092591

Giardino, C. (2019). Magan-The Land of Copper: Prehistoric Metallurgy of Oman. Oxford: Archaeopress Publishing, Ltd. https://doi.org/10.2307/j.ctvndv6cp

Golden, J. M. (2014). Dawn of the Metal Age: Technology and Society during the Levantine Chalcolithic. New York: Routledge.

Greenfield, H. J. (2017). The Spread of Productive and Technological Innovations in Europe and the Near East: An Integrated Zooarchaeological Perspective on Secondary Animal Products and Bronze Utilitarian Metallurgy. Appropriating Innovations: Entangled Knowledge in Eurasia, 5000-1500 BCE. Oxford: Oxbow Books.

Hardach, S. (2018). The Key to Cracking Long-Dead Languages? BBC.

https://www.bbc.com/future/article/20181207-how-ai-could-help-us-with-ancient-lang uag-

es-like-sumerian\#: :text=An\%20estimated $\% 20$ half $\% 20 \mathrm{a} \% 20$ million,of $\% 20$ cuneiform $\%$ 
20texts\%20remain\%20untranslated

Hauptmann, A. (2014). The Investigation of Archaeometallurgical Slag. In Archaeometallurgy in Global Perspective (pp. 91-105). New York: Springer. https://doi.org/10.1007/978-1-4614-9017-3_5

Helwing, B. (2017). A Comparative View on Metallurgical Innovations in South-Western Asia: What Came First? Appropriating Innovations: Entangled Knowledge in Eurasia, 5000-1500 BCE. Oxford: Oxbow Books.

Junk, M. (1973). Material Properties of Copper Alloy Containing Arsenic, Antimony, and Bismuth. Work Submitted as Doctorate Dissertation, Freiberg: Technischen Universität Bergakademie. https://tubaf.qucosa.de/api/qucosa\%3A22426/attachment/ATT-0

Kanika, B. (2021). Early Indus Civilization and Its Trade Relations. History Discussions. https://www.historydiscussion.net/history-of-india/indus-valley-civilisation/early-indu s-civilization-and-its-trade-relations-india-history/7058

Killick, D. (2009). Cairo to Cape: The Spread of Metallurgy through Eastern and Southern Africa. Journal of World Prehistory, 22, 399-414. https://doi.org/10.1007/s10963-009-9025-3

Leemans, W. F. (1960). Foreign Trade in the Old Babylonian Period, VI. Leiden: Studia et Documenta ad iura Orientis Antique Pertinentia.

Leick, G. (2001). Mesopotamia: The Invention of the City. London: Penguin Books.

Levey et al. (1959). A Study of Ancient Mesopotamian Bronze. Chymia, 5, 37-50. https://doi.org/10.2307/27757175

Levey, M. (1959). Chemistry and Chemical Technology in Ancient Mesopotamia. New York: Elsevier. https://doi.org/10.1111/j.1600-0498.1959.tb00254.x

Limet, H. (1955). Documents Économiques de la III e Dynastie D’Ur. Revue d'Assyriologie et d'Archéologie Orientale, 49, 69-93.

Lopez, A. M. (2009). Metalworking through History: An Encyclopedia. London: Greenwood Press.

Matthews, R., \& Fazeli, H. (2004). Copper and Complexity: Iran and Mesopotamia in the Fourth Millennium B.C. Journal of the British Institute of Persian Studies, 42, 61-75. https://doi.org/10.2307/4300663

Mieroop, M. (2016). A History of the Ancient near East: Ca. 3000-323 BC. Oxford: Wiley Blackwell.

Mödlinger, M. et al. (2017). Arsenic Loss during Metallurgical Processing of Arsenical Bronze. Archaeological and Anthropological Sciences, 11, 133-140. https://doi.org/10.1007/s12520-017-0534-1

Moorey, P. R. S. (1982). The Archaeological Evidence for Metallurgy and Related Technologies in Mesopotamia, c. 5500-2100 B.C. Iraq, 44, 13-38.

https://doi.org/10.2307/4200150

Moorey, P. R. S. (1988). The Chalcolithic Hoard from Nahal Mishmar, Israel, in Context. World Archaeology, 20, 171-189. https://doi.org/10.1080/00438243.1988.9980066

Moorey, P. R. S. (1999). Ancient Mesopotamian Materials and Industries: The Archaeological Evidence (p. 251). University Park, PA: Pennsylvania State University Press.

Morr, Z., Cattin, F. et al. (2013). Copper Quality and Provenance in Middle Bronze Age I Byblos and Tell Arqa (Lebanon). Journal of Archaeological Science, 40, 4291-4305. https://doi.org/10.1016/j.jas.2013.05.025

Muhly, J. D. (1973). Copper and Tin. Hamden, CT: The Connecticut Academy of Arts 
and Sciences.

Oakberg, K. et al. (2000). A Method for Skeletal Arsenic Analysis, Applied to the Chalcolithic Copper Smelting Site of Shiqmim, Israel. Journal of Archaeological Science, 27, 895-901. https://doi.org/10.1006/jasc.1999.0505

Oudbashi, O. et al. (2020). Arsenical Copper and Bronze Metallurgy during Late Bronze Age of North-Eastern Iran: Evidences from Shahrak-e Firouzeh Archaeological Site. Archaeological and Anthropological Sciences, 12, 231.

https://doi.org/10.1007/s12520-020-01182-3

Patterson, C. C. (1971). Native Copper, Silver, and Gold Accessible to Early Metallurgists. American Antiquity, 36, 286-321. https://doi.org/10.2307/277716

Pollock, S. (1999). Ancient Mesopotamia: The Eden That Never Was. Cambridge: Cambridge University Press.

Radivojević, M. et al. (2010). On the Origins of Extractive Metallurgy: New Evidence from Europe. Journal of Archaeological Science, 37, 2775-2787.

https://doi.org/10.1016/j.jas.2010.06.012

Raymond, R. (1986). Out of the Fiery Furnace: The Impact of Metals on the History of Mankind. University Park, PA: Pennsylvania State University Press.

Roberts, B. W. (2009). Development of Metallurgy in Eurasia. Antiquity, 83, 1012-1022. https://doi.org/10.1017/S0003598X00099312

Roth, M. T. (1995). Laws of Eshnunna. In Law Collections from Mesopotamia and Asia Minor (pp. 57-70). Atlanta, GA: Scholarship Press.

Ryck, I., Adriaens, A. et al. (2005). An Overview of Mesopotamian Bronze Metallurgy during the 3rd Millennium BC. Journal of Cultural Heritage, 6, 261-268.

Shibayama, A. et al. (2010). Treatment of Smelting Residue for Arsenic Removal and Recovery of Copper Using Pyro-Hydrometallurgical Process. Journal of Hazardous Material, 181, 1016-1023. https://doi.org/10.1016/j.jhazmat.2010.05.116

Stech, T. (1999). Aspects of Early Metallurgy in Mesopotamia and Anatolia. In The Archaeometallurgy of the Asian Old World (pp. 59-67). Ann Arbor, MI: University of Michigan Press.

Steinkeller, P. (2014). The Role of Iran in the Inter-Regional Exchange of Metals: Tin, Copper, Silver and Gold in the Second Half of the Third Millennium BC. Ancient Iran: New Perspectives from Archaeology and Cuneiform Studies. Proceedings of the International Colloquium, Kyoto, 6-7 December 2014, 127-150.

Strassmaier, J. N. (1889). Inschriften von Nabonidus. Leipzig: Verlag von Eduard Pfeiffer.

Svend, H. (2017). Key Techniques in the Production of Metals in the 6th and 5th Millennia BCE: Prerequisites, Preconditions and Consequences. In Appropriating Innovations: Entangled Knowledge in Eurasia, 5000-1500 BCE (pp. 136-149). Oxford: Oxbow Books. https://doi.org/10.2307/j.ctt1vgw6v1.14

Thompson, R. C. (1936). A Dictionary of Assyrian Chemistry and Geology. London: Oxford Press.

Thornton, C. P. (2009). The Emergence of Complex Metallurgy on the Iranian Plateau: Escaping the Levantine Paradigm. Journal of World Prehistory, 22, 301-327.

Tylecote, R. F. (1992). A History of Metallurgy. London: The Institute of Materials.

Wertime, T. et al. (1973). The Beginnings of Metallurgy: A New Look. Science, 30, 875-887. https://doi.org/10.1126/science.182.4115.875

Wischnewski, U. (2017). Appropriation of Tin-Bronze Technology: A Regional Study of 
the History of Metallurgy in Early Bronze Age Southern Mesopotamia. In Appropriating Innovations: Entangled Knowledge in Eurasia, 5000-1500 BCE (pp. 211-219). Oxford: Oxbow Books. https://doi.org/10.2307/j.ctt1vgw6v1.19

Wiseman, D. J. (1953). The Alalakh Tablets. London: British Institute of Archaeology.

Yener, K. A. et al. (1993). Tin Processing at Göltepe, an Early Bronze Age Site in Anatolia. American Journal of Archaeology, 97, 207-238. https://doi.org/10.2307/505657

Zettler, R. L., \& Lee, H. (1999). Treasures from the Royal Tombs of Ur. Philadelphia, PA: University of Pennsylvania. 